\title{
Waste biomass as sources for activated carbon production-A review
}

\author{
M. S. Islam and M. A. Rouf* \\ Institue of Fuel Research \& Development, Bangladesh Council of Scientific \& Industrial Research, \\ Dr. Kudrat-e-Khuda Road, Dhanmondi, Dhaka-1205, Bangladesh
}

\begin{abstract}
A review of the production of activated carbons from waste biomass has been presented. The effects of various process parameters on the pyrolysis stage have been reviewed. Influences of activating conditions, physical and chemical, on the active carbon properties have been discussed. Under certain process conditions several active carbons with BET surface areas, ranging between 250 and $2410 \mathrm{~m}^{2} / \mathrm{g}$ and pore volumes of 0.022 and $91.4 \mathrm{~cm}^{3} / \mathrm{g}$, have been produced. A comparison in characteristics and uses of activated carbons from waste biomass with those of commercial carbons has been made. Waste biomass being highly efficient, low cost and renewable sources of activated carbon production.
\end{abstract}

Keywords: Activated carbons; Waste biomass; Pyrolysis; Renewable sources

\section{Introduction}

Thermo-chemical processes such as pyrolysis or gasification have been widely applied to biomass gain due to its energy content. Pyrolysis is one form of energy recovery processes, which has the potential to generate char, oil and gas product (Putun et al., 2005). Because of the thermal treatment, which removes the moisture and the volatile matters of the biomass, the remaining solid char shows different properties than the parent biomass materials. The remarkable differences are mainly in porosity, surface area, pore structures (micropores, mesopores and macropores) and physicochemical properties such as composition, elemental analysis and ash content (Haykiri-Acma et al., 2005). These changes in the properties usually lead to high reactivity, and hence, an alternative usage of char as an adsorbent material becomes possible (Putun et al., 2005). Thus, the char becomes an attractive by-product, with applications including production of activated carbons (ACs), which is useful as a sorbent for air pollution control as well as for wastewater treatment (Fan et al., 2004). ACs are carbons of highly microporous form with both high internal surface area and porosity, and commercially the most common adsorbents used for the removal of organic compounds from air and water streams. They also often serve as catalysts and catalyst supports.

The process parameters, which have the largest influence on the products of pyrolysis, are the particle size, temperature and heating rate. The process conditions can be optimized to maximize the production of the pyrolytic char, oil or gas, all of which have potential uses as fuels. Any cheap material, with a high carbon content and low inorganics, can be used as a raw material for the production of AC (Tsai et al., 1997); agricultural by-products have proved to be promising raw materials for the production of ACs because of their availability at a low price. They can be used for the production of AC with a high adsorption capacity, considerable mechanical strength, and low ash content (Savova et al., 2001). Literature survey indicates that there have been many attempts to obtain low-cost AC or adsorbent from agricultural wastes such as wheat (Lanzetta and Di Blasi, 1998), corn straw (Lanzetta and Di Blasi, 1998), olive stones (Minkova et al., 2001) and (Minkova et al., 2000), bagasse (Minkova et al., 2001) and (Minkova et al., 2000), birch wood (Minkova et al., 2001) and (Minkova et al., 2000), miscanthus (Minkova et al., 2001) and (Minkova et al., 2000), sunflower shell, pinecone, rapeseed (Haykiri-Acma et al., 2005) and (Predel and Kaminsky, 1998), cotton residues, olive residues (Haykiri-Acma et al., 2005), pine rayed, eucalyptus maculata, sugar cane bagasse (Cetin et al., 2004) and (Ahmedna et al., 2000), almond shells (Savova et al., 2001), (Aygun et al., 2003) and (Marcilla et al., 2000), peach stones (Tsai et al., 1997), grape seeds (Savova et al., 2001), straw (Minkova et al., 2001), (Minkova et al., 2000) and (Jensen et al., 2001), oat hulls (Fan et al., 2004) and (Zhang et al., 2004), corn stover (Fan et al., 2004) and (Zhang et al.2004), apricot stones (Savova et al., 2001) and (Aygun et al., 2003), cotton stalk (Putun et al., 2005), cherry stones (Savova et al.,

*Corresponding author. E-mail: roufmd@yahoo.com 
2001), peanut hull (Girgis et al., 2002), nut shells (Savova et al., 2001), (Lua et al., 2004) , (Ahmadroup and Do, 1997), (Yang and Lua, 2003) and (Ahmedna et al., 2004), rice hulls (Ahmedna et al., 2000), corn cob (Tsai et al.1997), (Tsai et al., 1998), (Tsai et al., 2001) and (El-Hendawy et al., 2001), corn hulls (Zhang et al., 2004), hazelnut shells (Aygun et al., 2003), pecan shells (Ahmedna et al., 2000), bamboo waste (Mahanim et al., 2011), rice husks (Malik, 2003) and (Yalcin and Sevinc, 2000) and rice straw (Ahmedna et al., 2000) and (Oh and Park, 2002). The purpose of the present review is the evaluation of the experimental data that were determined for various types of residues, reported in the literature. Given that solid devolatilization is always a fundamental step, Thermo gravimetric analysis (TGA) technique has been applied in several cases. Bangladesh has enormous amount of biomass resources, but not much scientific research has yet been done to produce activated carbon from the substance. The literature review on activated carbon production will therefore, be useful for the development of research of activated carbon and its applications in Bangladesh.

\section{Experimental conditions for carbon production from waste biomass}

Pyrolysis

Waste biomass are produced in huge amounts worldwide, their proximate and ultimate analysis are presented in Table I, while Table II presents some carbonization and activation conditions for the production of the ACs from waste biomass.

Corn stover with oat hulls for activated carbon production by TGA was studied (Fan et al., 2004). There was no pre-treatment prior to fast pyrolysis that was held in a nitrogen fluidized bed reactor at a typical biomass feed of $7 \mathrm{~kg} / \mathrm{h}$. Zhang et al., (2004) studied oak wood wastes, corn hulls and corn stover carbonization in a fluidized bed reactor at $500{ }^{\circ} \mathrm{C}$. In the study of Haykiri-Acma et al. 2005, TGA was used to pyrolyse and then gasifies chars obtained from sunflower shell, pinecone, rapeseed, cotton and olive residues pyrolysis. The chars obtained were heated in order to gasify under steam and nitrogen atmosphere and in equal volumetric ratio. For pinus radiate, eycalyptus maculate and sugar cane bagasse, atmospheric reactivity measurements were performed under isothermal conditions, using a thermogravimetric analyser (Cetin et al., 2004). The heat up was carried out at a nominal heating rate of $40{ }^{\circ} \mathrm{C} \mathrm{min}{ }^{-1}$. Sugarcane bagasse, rice hulls, rice straw, and pecan shells were also studied (Ahmedna et al., 2000), in an atmosphere of nitrogen gas at $750{ }^{\circ} \mathrm{C}$ using an inert atmosphere furnace with retort. Chars were activated until approximately $30 \%$ burn-off was achieved.

Pyrolysis temperature has the most significant effect-followed by pyrolysis heating rate, the nitrogen flow rate and

Table I. Waste biomass availability, proximate and ultimate analysis (Skoulou and Zabaniotou, 2007)

\begin{tabular}{lccccccccc}
\hline Agricultural wastes & $\begin{array}{c}\text { Moisture, \% } \\
(\mathrm{w} / \mathrm{w})\end{array}$ & $\begin{array}{c}\text { Ash, \% } \\
(\mathrm{w} / \mathrm{w})\end{array}$ & $\begin{array}{c}\text { Volatiles, \% } \\
(\mathrm{w} / \mathrm{w})\end{array}$ & $\begin{array}{c}\mathrm{C}, \% \\
(\mathrm{w} / \mathrm{w})\end{array}$ & $\begin{array}{c}\mathrm{H}, \% \\
(\mathrm{w} / \mathrm{w})\end{array}$ & $\begin{array}{c}\mathrm{O}, \% \\
(\mathrm{w} / \mathrm{w})\end{array}$ & $\begin{array}{c}\mathrm{N}, \% \\
(\mathrm{w} / \mathrm{w})\end{array}$ & $\begin{array}{c}\mathrm{S}, \% \\
(\mathrm{w} / \mathrm{w})\end{array}$ & $\begin{array}{c}\mathrm{HHV}, \\
\mathrm{kcal} / \mathrm{kg}\end{array}$ \\
\hline Olive tree prunings & 7.1 & 4.75 & - & 49.9 & 6 & 43.4 & 0.7 & & 4500 \\
Cotton stalks & 6 & 13.3 & - & 41.23 & 5.03 & 34 & 2.63 & 0 & 3772 \\
Durum wheat straw & 40 & - & - & - & - & - & - & - & 4278 \\
Corn stalks & 0 & 6.4 & - & 45.53 & 6.15 & 41.11 & 0.78 & 0.13 & 4253 \\
Soft wheat straw & 15 & 13.7 & 69.8 & - & - & - & - & - & 4278 \\
Vineyward prunings & 40 & 3.8 & - & 47.6 & 5.6 & 41.1 & 1.8 & 0.08 & 4011 \\
Corn cobs & 7.1 & 5.34 & - & 46.3 & 5.6 & 42.19 & 0.57 & 0 & 4300 \\
Sugar beet leaves & 75 & 4.8 & - & 44.5 & 5.9 & 42.8 & 1.84 & 0.13 & 4230 \\
Barley straw & 15 & 4.9 & - & 46.8 & 5.53 & 41.9 & 0.41 & 0.06 & 4489 \\
Rice straw & 25 & 13.4 & 69.3 & 41.8 & 4.63 & 36.6 & 0.7 & 0.08 & 2900 \\
Peach tree prunings & 40 & 1 & 79.1 & 53 & 5.9 & 39.1 & 0.32 & 0.05 & 4500 \\
Almond tree prunings & 40 & n.a & - & - & - & - & - & - & 4398 \\
Oats straw & 15 & 4.9 & - & 46 & 5.91 & 43.5 & 1.13 & 0.015 & 4321 \\
Sunflower straw & 40 & 3 & - & 52.9 & 6.58 & 35.9 & 1.38 & 0.15 & 4971 \\
Cherry tree prunings & 40 & 1 & 84.2 & - & - & - & - & - & 5198 \\
Apricot tree prunings & 40 & 0.2 & 80.4 & 51.4 & 6.29 & 41.2 & 0.8 & 0.1 & 4971 \\
\hline
\end{tabular}




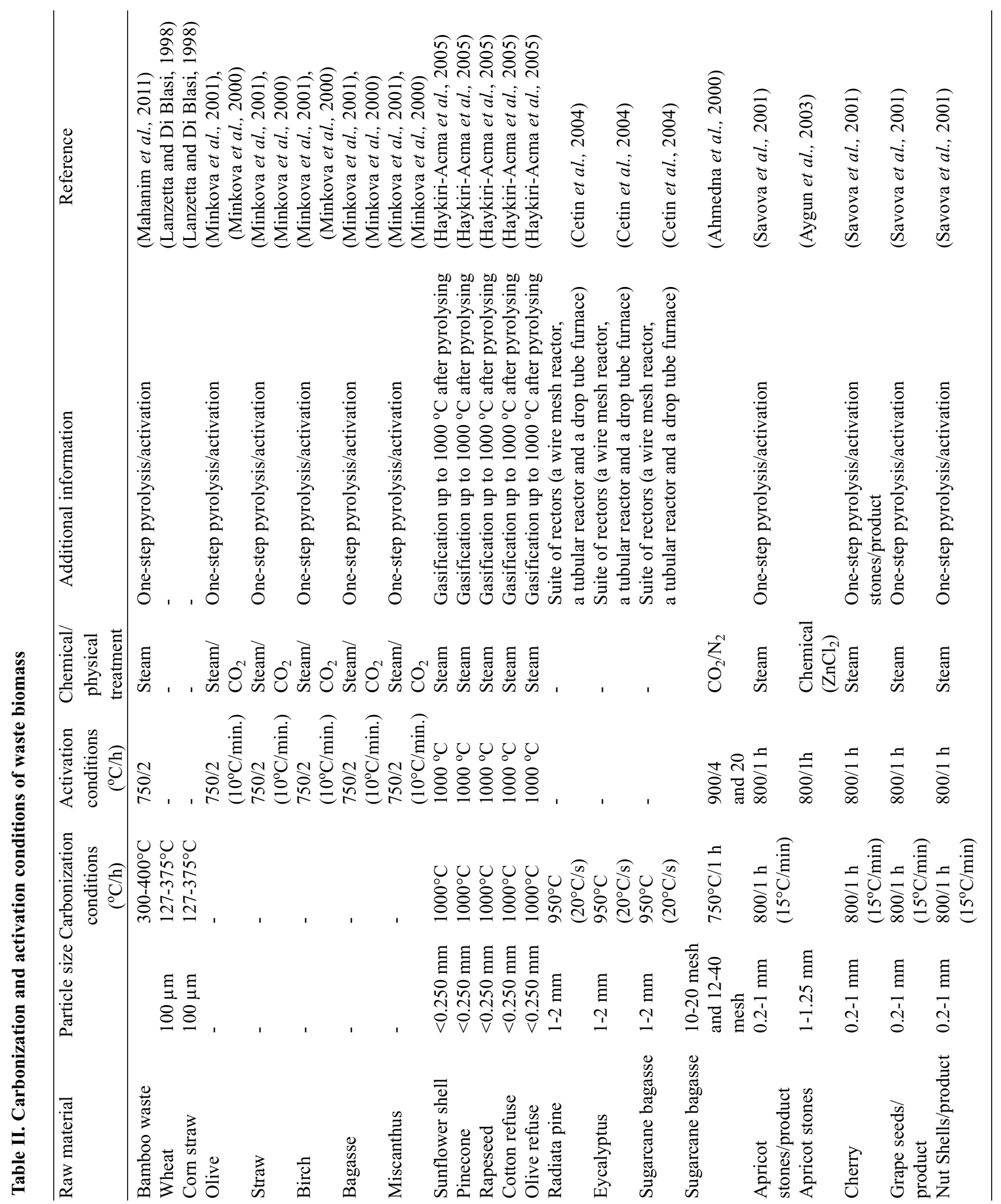




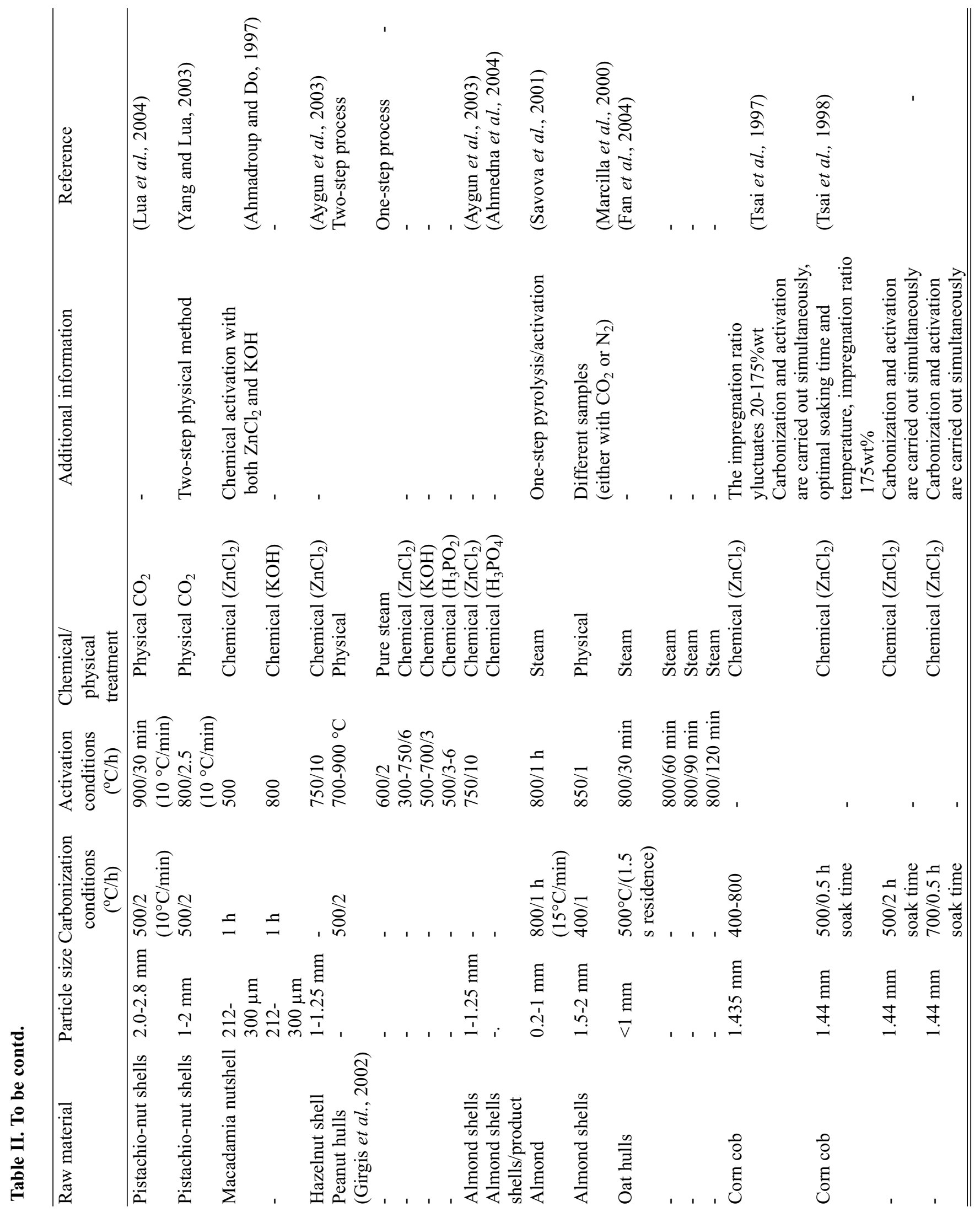


Islam and Rouf

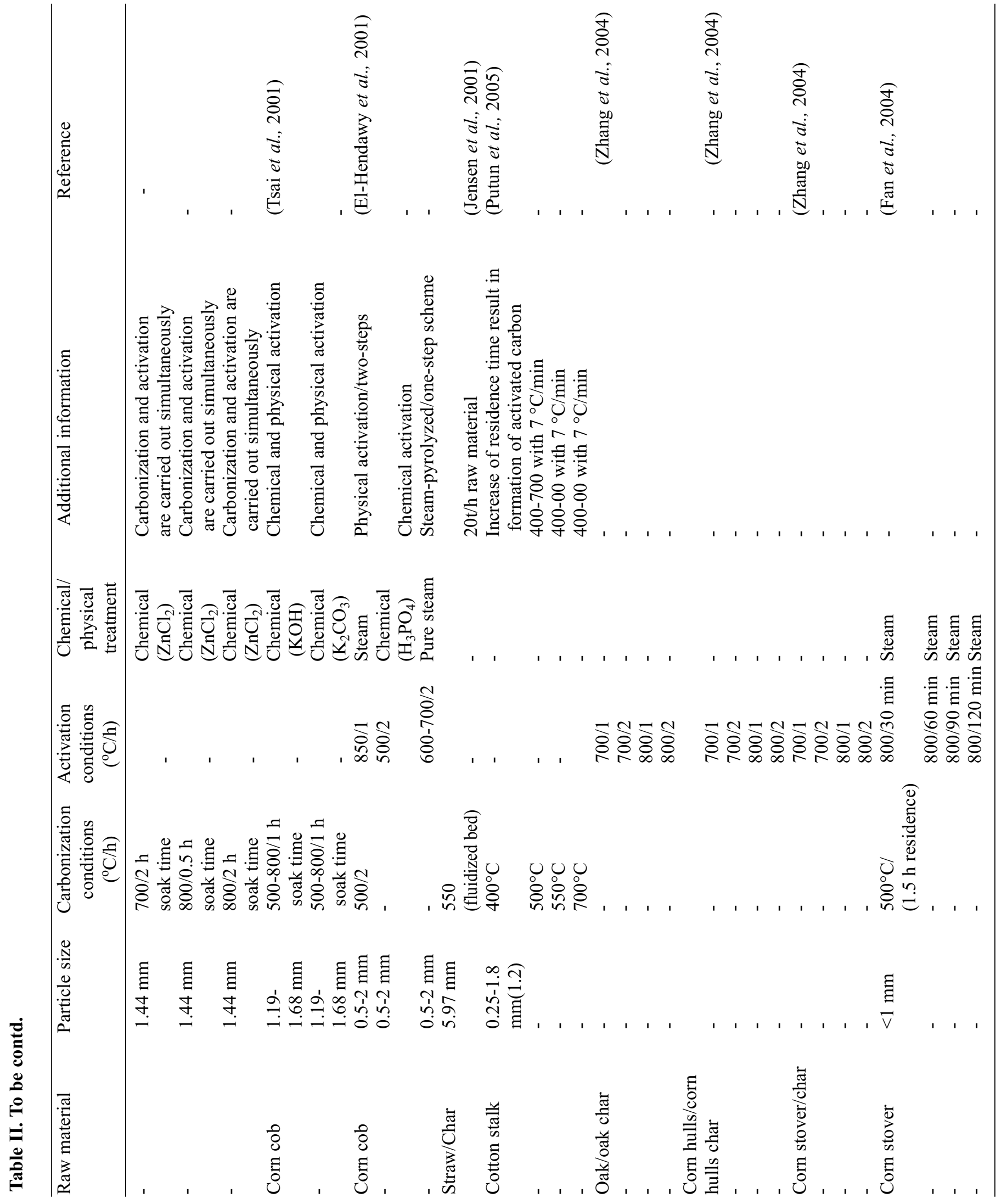




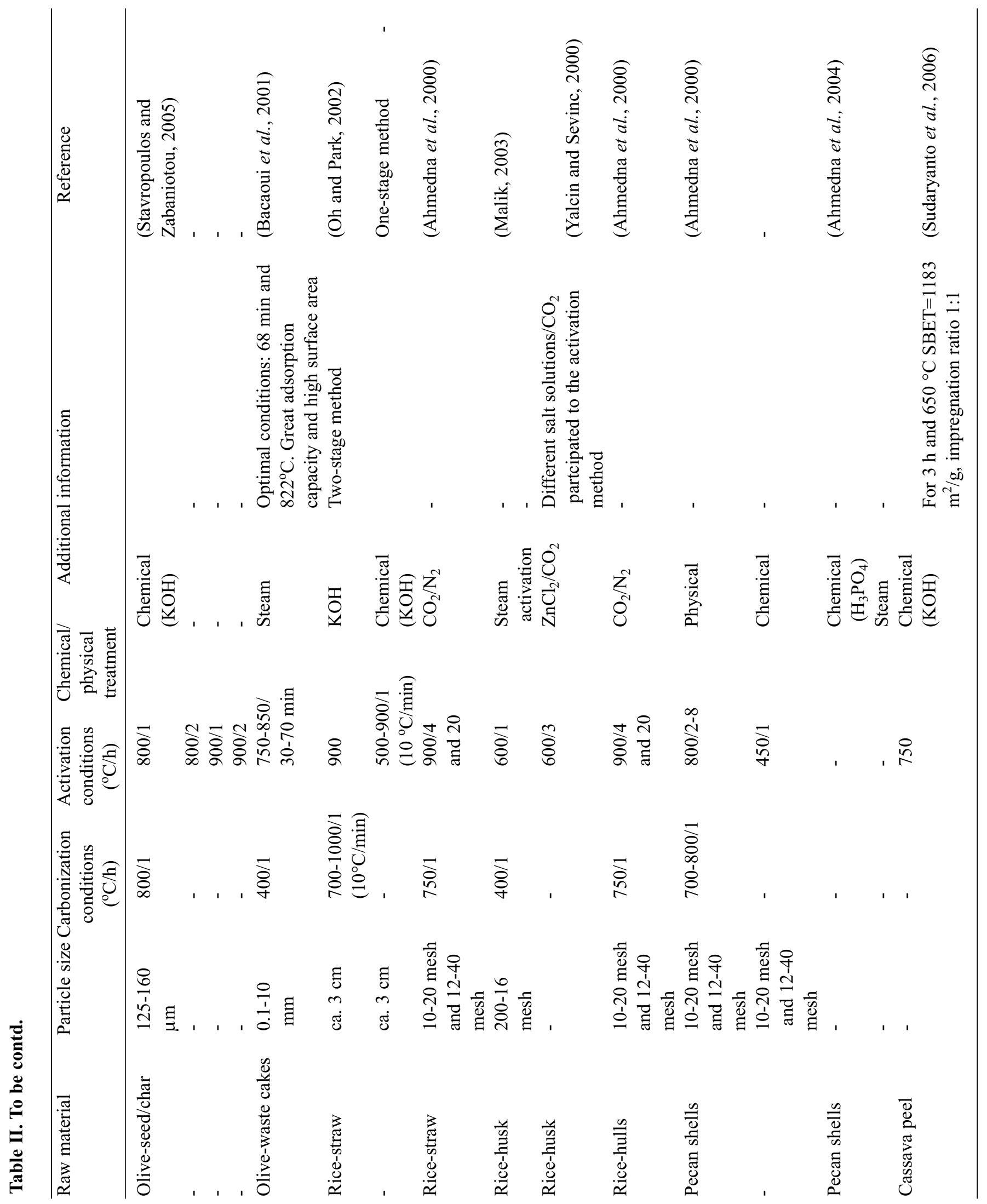


then finally the pyrolysis residence time. Generally, increasing pyrolysis temperature reduces yields of both chars and ACs. According to Putun et al., 2005, increased temperature leads to a decreased yield of solid and an increased yield of liquid and gases. As the temperature is raised, there is a rise in ash and fixed carbon percentage and there is a decrease in volatile matter. Consequently, higher temperature yields charcoals of greater quality. The decrease in the char yield with increasing temperature could either be due to greater primary decomposition of biomass at higher temperatures or through secondary decomposition of char residue. The secondary decomposition of the char at higher temperatures may also give some non-condensable gaseous products, which also contributes to the increase in gas yield. Indeed, as the temperatures of primary degradation are increased or the residence times of primary vapours inside the cracked particle has to stay shorter, the char yields decrease (Putun et al., 2005). Temperature dependence was also studied (Tsai et al., 1997) and (Tsai et al., 1998) for preparation of ACs with chemical activation $\left(\mathrm{ZnCl}_{2}\right)$, where it was noticed that char yield decreases with temperature, while soaking time had no effect on the char yield.

\section{Activation}

Basically, there are two main steps for the preparation and manufacture of AC: (1) the carbonization of the carbona ceous raw material below $800{ }^{\circ} \mathrm{C}$, in the absence of oxygen, and (2) the activation of the carbonized product (char), which is either physical or chemical. The types of activation are represented in Table III.

\section{Physical activation}

Physical activation is a two-step process. It involves carbonization of a carbonaceous material followed by the activation of the resulting char at elevated temperature in the presence of suitable oxidizing gases such as carbon dioxide, steam, air or their mixtures, as it can be seen in Table IV. The activation gas is usually $\mathrm{CO}_{2}$, since it is clean, easy to handle and it facilitates control of the activation process due to the slow reaction rate at temperatures around $800{ }^{\circ} \mathrm{C}$ (Zhang et al., 2004). Rice husk, corn cob, oak, corn hulls, corn stover, rice straw, rice hulls, pecan shells, peanut hulls and almond shells (Haykiri-Acma et al., 2005), (Ahmedna et al., 2000), (Marcilla et al., 2000), (Zhang et al., 2004), (Girgis et al., 2002), (Lua et al., 2004), (Yang and Lua, 2003), (ElHendawy et al., 2001), (Malik, 2003), (Yalcin and Sevinc, 2000) and (Oh and Park, 2002), were the raw materials studied by this method. Carbonization temperature range between 400 and $850{ }^{\circ} \mathrm{C}$, and sometimes reaches $1000{ }^{\circ} \mathrm{C}$, and activation temperature range between 600 and $900{ }^{\circ} \mathrm{C}$.

Table III. Types of activation

\begin{tabular}{|c|c|c|c|}
\hline Material & Activation & $\begin{array}{l}\text { Steps of } \\
\text { process }\end{array}$ & Reference \\
\hline $\begin{array}{l}\text { Pistachio-nutshells, sunflower shells, } \\
\text { pinecone, rapeseed, cotton residues, } \\
\text { olive residues, peanut hulls, almond } \\
\text { shells, oak, corn hulls, corn stover, } \\
\text { rice straw, rice husk, rice hulls, pecan } \\
\text { shells, sugarcane bagasse, olive- } \\
\text { waste cakes }\end{array}$ & Physical & Two-steps & $\begin{array}{l}\text { (Haykiri-Acma et al., 2005), (Ahmedna et al., 2000), } \\
\text { (Marcilla et al., 2000), (Zhang et al., 2004), (Girgis } \\
\text { et al., 2002), (Lua et al., 2004), (Yang and Lua, } \\
\text { 2003), (El-Hendawy et al., 2001), (Malik, 2003), } \\
\text { (Oh and Park, 2002) and (Bacaoui et al., 2001) }\end{array}$ \\
\hline $\begin{array}{l}\text { Corn cob, olive seeds, rice husks, rice } \\
\text { straw, cassava peel, pecan shells, } \\
\text { Macadamia nutshells, hazelnut } \\
\text { shells, peanut hulls, apricot stones, } \\
\text { almond shells }\end{array}$ & Chemical & One-step & $\begin{array}{l}\text { (Tsai et al., 1997), (Aygun et al., 2003), (Girgis et al., } \\
\text { 2002), (Ahmadroup and Do, 1997), (Ahmedna et al., } \\
\text { 2004), (Tsai et al., 1998), (Tsai et al., 2001), (El- } \\
\text { Hendawy et al., 2001), (Yalcin and Sevinc, 2000), } \\
\text { (Oh and Park, 2002), (Stavropoulos and Zabaniotou, } \\
\text { 2005) and (Sudaryanto et al., 2006) }\end{array}$ \\
\hline $\begin{array}{l}\text { Olive, straw, birch, bagasse, miscant- } \\
\text { hus, peanut hulls, corn stover, apricot } \\
\text { stones, cherry stones, grape seeds, } \\
\text { nutshells, almond shells, oat hulls }\end{array}$ & Steam-Pyrolysis & One-step & $\begin{array}{l}\text { (Fan et al., 2004), (Savova et al., 2001), (Minkova et } \\
\text { al., 2001), (Minkova et al., 2000), (Girgis et al., } \\
\text { 2002) and (El-Hendawy et al., 2001) }\end{array}$ \\
\hline
\end{tabular}


Table IV. Physical activation of waste biomass, reported in the literature

\begin{tabular}{|c|c|c|}
\hline \multicolumn{2}{|c|}{ Material } & Reference \\
\hline Steam & $\begin{array}{l}\text { Rice husk, corn cob, olive residues, sunflower shells, pinecone, } \\
\text { rapeseed, cotton residues, olive-waste cakes, bamboo }\end{array}$ & $\begin{array}{l}\text { (Haykiri-Acma et al., 2005), (El-Hendawy et al., } \\
\text { 2001), (Malik, 2003) and (Mahanim et al., 2011) }\end{array}$ \\
\hline $\mathrm{CO}_{2}$ & $\begin{array}{l}\text { Oak, corn hulls, corn stover, rice straw, rice hulls, pecan shells, } \\
\text { Pistachio nutshells, sugarcane bagasse }\end{array}$ & $\begin{array}{l}\text { (Ahmedna et al., 2000), (Zhang et al., 2004), (Lua } \\
\text { et al., 2004) and (Yang and Lua, 2003) }\end{array}$ \\
\hline & Peanut hulls, almond shells & (Marcilla et al., 2000) and (Girgis et al., 2002) \\
\hline
\end{tabular}

Physical activation of oak, corn hulls and corn stover chars (Zhang et al., 2004), was performed at temperatures of 700 and $800{ }^{\circ} \mathrm{C}$ and durations of 1 and $2 \mathrm{~h}$. For oak, the longer the activation duration, the greater the adsorption capacity of the resultant ACs, and vice-versa for the corn hulls and corn stover. Apparently, the activation durations of 1 and $2 \mathrm{~h}$ did not appreciably affect the properties of ACs from oak at $700^{\circ} \mathrm{C}$. In contrast, the surface areas, total pore volume, and pore volume of AC obtained upon $1 \mathrm{~h}$ of activation were much less than those upon $2 \mathrm{~h}$ of activation at $800{ }^{\circ} \mathrm{C}$. Obviously, the pore structure of carbons from oak altered substantially for different durations of activation at $800{ }^{\circ} \mathrm{C}$. The surface areas and pore volumes of ACs from chars generated from corn hulls as well as from corn stover were appreciably greater after $1 \mathrm{~h}$ of activation than after $2 \mathrm{~h}$ of activation. This was in sharp contrast to the results from the activation of char from oak. Plausibly, in activating the chars from both corn hulls and corn stover, the rate of pore structure formation exceeded that of the destruction due to the pore enlargement and collapse at the earlier stage and vice versa at the later stage. A more thorough research for corn cobs was made (El-Hendawy et al., 2001). The char was carbonized at $500{ }^{\circ} \mathrm{C}$, then soaked for $2 \mathrm{~h}$, and steam-activated at $850{ }^{\circ} \mathrm{C}$ in a flow of steam $/ \mathrm{N}_{2}$, for $1 \mathrm{~h}$.

\section{Chemical activation}

In the chemical activation process the two steps are carried out simultaneously, with the precursor being mixed with chemical activating agents, as dehydrating agents and oxidants. Chemical activation offers several advantages since it is carried out in a single step, combining carbonization and activation, performed at lower temperatures and therefore resulting in the development of a better porous structure, although the environmental concerns of using chemical agents for activation could be developed. Besides, part of the added chemicals (such as zinc salts and phosphoric acid), can be easily recovered (Tsai et al., 1997), (Zhang et al., 2004) and (Tsai et al., 1998). However, a two-step process (an admixed method of physical and chemical processes) can be applied (Oh and Park, 2002), (Table V).

Table V. Chemical activation of waste biomass

\begin{tabular}{|c|c|c|}
\hline $\begin{array}{c}\text { Activating } \\
\text { agent }\end{array}$ & Material & Reference \\
\hline $\mathrm{ZnCl}_{2}$ & $\begin{array}{l}\text { Corn cob, Macadamia nutshells, peanut hulls, almond } \\
\text { shells, hazelnut shells, apricot stones, rice husks }\end{array}$ & $\begin{array}{l}\text { (Tsai et al., 1997), (Aygun et al., 2003), (Girgis et } \\
\text { al., 2002), (Ahmadroup and Do, 1997), (Tsai et al., } \\
\text { 1998) and (Yalcin and Sevinc, 2000) }\end{array}$ \\
\hline $\mathrm{KOH}$ & $\begin{array}{l}\text { Corn cob, Macadamia nutshells, peanut hulls, olive seed, } \\
\text { rice straw, Cassava peel }\end{array}$ & $\begin{array}{l}\text { (Girgis et al., 2002), (Ahmadroup and Do, 1997), } \\
\text { (Tsai et al., 2001), (Oh and Park, 2002), } \\
\text { (Stavropoulos and Zabaniotou, 2005) and } \\
\text { (Sudaryanto et al., 2006) }\end{array}$ \\
\hline $\mathrm{H}_{3} \mathrm{PO}_{4}$ & peanut hulls, almond shells, pecan shells, corn cob & $\begin{array}{l}\text { (Girgis et al., 2002), (Ahmedna et al., 2004) and } \\
\text { (El-Hendawy et al., 2001) }\end{array}$ \\
\hline $\mathrm{K}_{2} \mathrm{CO}_{3}$ & Corn cob & (Tsai et al., 2001) \\
\hline
\end{tabular}


Chemical activation was used in most of the studies for corn cob, olive seeds, rice husks, rice straw, cassava peel, pecan shells, Macadamia nutshells, hazelnut shells, peanut hulls, apricot stones, almond shells (Tsai et al., 1997), (Aygun et al., 2003), (Girgis et al., 2002), (Ahmadroup and Do, 1997), (Ahmedna et al., 2004), (Tsai et al., 1998), (Tsai et al., 2001), (El-Hendawy et al., 2001), (Yalcin and Sevinc, 2000), (Oh and Park, 2002), (Stavropoulos and Zabaniotou, 2005) and (Sudaryanto et al., 2006). The most common chemical agents are $\mathrm{ZnCl}_{2}, \mathrm{KOH}, \mathrm{H}_{3} \mathrm{PO}_{4}$ and less $\mathrm{K}_{2} \mathrm{CO}_{3}$. As it can be seen almond shells, hazelnut shells and apricot stones (Aygun et al., 2003), were activated with a solution of $\mathrm{ZnCl}_{2}$ (30 wt $\%$ ) at $750-800-850^{\circ} \mathrm{C}$, respectively, for $2 \mathrm{~h}$. Zinc chloride was also used in the study (Tsai et al., 1997) and (Tsai et al., 1998), for the activation of carbons from corn cob in the range of $400-800{ }^{\circ} \mathrm{C}$, for $0.5-4.0 \mathrm{~h}$ of soaking time, and as well in the study of (Girgis et al., 2002), where a $50 \%$ solution was mixed with sample of peanut hulls at 300-750 ${ }^{\circ} \mathrm{C}$ for $6 \mathrm{~h}$. Additionally, $\mathrm{ZnCl}_{2}$ was used as an activating agent for Macadamia nutshells (Ahmadroup and Do, 1997), and rice husks (Yalcin and Sevinc, 2000), at $500{ }^{\circ} \mathrm{C}$ for $1 \mathrm{~h}$, and at $600{ }^{\circ} \mathrm{C}$ for $3 \mathrm{~h}$ in combination with $\mathrm{CO}_{2}$, respectively, and gave the best characteristics of the activated carbons than with any other agent (chemical or physical).

Carbons from Macadamia nutshells (Ahmadroup and Do, 1997), and peanut hulls (Girgis et al., 2002), were activated with $\mathrm{KOH}$ at $800{ }^{\circ} \mathrm{C}$ for $1 \mathrm{~h}$ and $500-700{ }^{\circ} \mathrm{C}$ for $3 \mathrm{~h}$, respectively. ACs that were produced, did not have good quality as the ones produced with $\mathrm{ZnCl}_{2}$. Corn cob char (Tsai et al., 2001), that was activated with $\mathrm{KOH}$ at $500-800{ }^{\circ} \mathrm{C}$ for $1 \mathrm{~h}$, did not generally give $\mathrm{AC}$ with such good BET surface area $\left(\mathrm{S}_{\mathrm{BET}}\right)$. Activation of olive seed carbons (Stavropoulos and Zabaniotou, 2005), took place at $800-900{ }^{\circ} \mathrm{C}$ for $1-2 \mathrm{~h}$ and gave ACs with high surface area and char yield. For rice straw char (Oh and Park, 2002), activation proceeded firstly in one-stage at $500-900{ }^{\circ} \mathrm{C}$ for $1 \mathrm{~h}$ and secondly in twostages, at $700-1000{ }^{\circ} \mathrm{C}$ for $1 \mathrm{~h}$ (carbonization conditions) and then at $900^{\circ} \mathrm{C}$ for the activation. Cassava peel char (Sudaryanto et al., 2006), activated at 650 and $750{ }^{\circ} \mathrm{C}$, the higher $\mathrm{S}_{\mathrm{BET}}$ appeared in the second case.

From the results, it becomes very obvious that the two-stage process is much more effective, as it gave ACs with higher porosity. In fact, this method (two-step chemical activation process), gave the higher surface area from all the studies being mentioned in the present review.

Activation with $\mathrm{H}_{3} \mathrm{PO}_{4}$ was used for carbons from peanut hulls (Girgis et al., 2002), corn cob (El-Hendawy et al., 2001), almond shells and pecan shells (Ahmedna et al., 2004). The activating conditions for peanut hull chars were $500{ }^{\circ} \mathrm{C}$ for $3 \mathrm{~h}$, while for corn cob chars $500{ }^{\circ} \mathrm{C}$ for $2 \mathrm{~h}$. Corn cob gave better characteristics of the ACs in the respective research than peanut hull. Almond shell chars activated with $\mathrm{H}_{3} \mathrm{PO}_{4}$ gave carbons with a little lower surface area than those mixed with $\mathrm{ZnCl}_{2}$.

Carbons from corn cob (Tsai et al., 2001), were activated with $\mathrm{K}_{2} \mathrm{CO}_{3}$ at $500-800{ }^{\circ} \mathrm{C}$ for $1 \mathrm{~h}$, where the ACs produced, comparatively with the results with $\mathrm{KOH}$, had a lower surface area and gave the maximum char yield.

\section{Steam pyrolysis/activation}

There is also an additional one-step treatment route, denoted as steam-pyrolysis (Table VI) as reported (Fan et al., 2004), (Savova et al., 2001), (Minkova et al., 2001), (Minkova et al., 2000), (Girgis et al., 2002) and (El-Hendawy et al., 2001), where the raw agricultural residue is either heated at moderate temperatures $\left(500-800{ }^{\circ} \mathrm{C}\right)$ under a flow of steam. The residues studied with this method were olive, straw, birch, bagasse, miscanthus, apricot stones, cherry stones, grape seeds, nutshells, almond shells, oat hulls, corn stover, and peanut hulls. The samples in the study of Minkova et al., 2001 , were heated with a heating rate of $10^{\circ} \mathrm{C} / \mathrm{min}$ to a final temperature of $700{ }^{\circ} \mathrm{C}, 750{ }^{\circ} \mathrm{C}$ or $800^{\circ} \mathrm{C}$ and kept 1 or $2 \mathrm{~h}$ at

Table VI. Steam-pyrolysis activation in one-step process of waste biomass

\begin{tabular}{|c|c|c|}
\hline & Material & Reference \\
\hline Steam & $\begin{array}{l}\text { Olive, straw, birch, bagasse, miscanthus, apricot stones, } \\
\text { cherry stones, grape seeds, nutshells, almond shells, oat } \\
\text { hulls, corn stover }\end{array}$ & $\begin{array}{l}\text { (Fan et al., 2004), (Savova et al., 2001), (Minkova } \\
\text { et al., 2001) and (Minkova et al., 2000) }\end{array}$ \\
\hline $\begin{array}{l}\text { Pure } \\
\text { steam }\end{array}$ & Peanut hulls, corn cob & $\begin{array}{l}\text { (Lanzetta and Di Blasi, 1998) and (El-Hendawy et } \\
\text { al., 2001) }\end{array}$ \\
\hline
\end{tabular}


this temperature in the flow of steam, while the final carbonization temperature in the study of Savova et al., 2001 was $80{ }^{\circ} \mathrm{C}$ for $1 \mathrm{~h}$

For the preparation and characterization of $\mathrm{AC}$ derived from oat hulls or corn stover (Fan et al., 2004), char was heated at $800{ }^{\circ} \mathrm{C}$ for $30,60,90$ and $120 \mathrm{~min}$. The ACs, which had a high pore volume, was weighed to determine activation burn-off or mass loss due to activation.

The burn-off refers to the weight difference between the original char and the AC divided by the weight of original char with both weights on a dry basis. The following relationship is used for calculating the activation burn-off of biomass-derived chars:

Activation burn-off $(\%)=100-\{[$ mass after activation $(\mathrm{g}) /$ original mass $(\mathrm{g})] \times 100$ \}

$\Rightarrow$ burn-of $=\frac{\mathrm{W}_{0}-\mathrm{W}_{1}}{\mathrm{~W}_{0}} \times 100 \%$,

where $W_{0}$ is the weight of char and $W_{1}$ the mass of the carbon after activation.

The activated carbons, produced by steam gasification, were generally proved to be weakly affective, except the ones from almond shell, apricot and cherry stones (Savova et al., 2001).

\section{Properties and characteristics of active carbons}

\section{Surface area}

The surface area of char is important because, like other physico-chemical characteristics, it strongly affect the reactivity and combustion behaviour of the char. The chars from pyrolysis above $400{ }^{\circ} \mathrm{C}$ had a surface area and a high surface area formed (Putun et al., 2005). In the study of Tsai et al., 1997 and 1998 surface areas were observed to decrease at higher pyrolysis temperature and soaking time. The higher surface areas are probably due to the opening of the restricted pores. The percentage of micropore followed the increase of pyrolysis temperature, but this rate of increase was not as fast as the rate of declination in surface areas. The BET surface areas which calculated in the research of Tsai et al., 1997 and 1998 were observed to increase at higher activation temperature, for both $\mathrm{KOH}$ and $\mathrm{K}_{2} \mathrm{CO}_{3}$ series, and the maximum rate of increase in BET surface area occurred between 650 and $700{ }^{\circ} \mathrm{C}$.

\section{Pore size and volume}

Both the size and distribution of micropores, mesopores and macropores determine the adsorptive properties of ACs. For instance, small pore size will not trap large adsorbate molecules and large pores may not be able to retain small adsorbates, whether they are charged polar molecules or uncharged non-polar compounds (Ahmedna et al., 2004).

Materials with a greater content of lignin (grape seeds, cherry stones) develop ACs with macroporous structure, while raw materials with a higher content of cellulose (apricot stones, almond shells) yield AC with a predominantly microporous structure (Savova et al., 2001).

The pore size, in the study of Tsai et al., 1997 and 1998 which was determined after chemical activation with $\mathrm{ZnCl}_{2}$, was calculated on the basis of desorption data by employing the Barrett-Joyner-Halenda (BJH) method. As it can be observed in Table VII, the total pore volume is decreasing not only with the increase of the temperature, but also with the increase of the soaking time when the temperature is constant. On the contrary, in the research of Tsai et al., 1997 and 1998 the values of total pore volume increase rapidly with increase in the activation temperature. It is noted that the maximum values (i.e. 0.87 and $0.74 \mathrm{~cm}^{3} / \mathrm{g}$ for $15 \mathrm{wt} \% \mathrm{KOH}$ and $37.5 \mathrm{wt} \% \mathrm{~K}_{2} \mathrm{CO}_{3} \mathrm{ACs}$, respectively) of total pore volume at $800{ }^{\circ} \mathrm{C}$, are larger than those of commercial ACs, i.e. 0.60 and $0.52 \mathrm{~cm}^{3} / \mathrm{g}$ for BPL and PCB, respectively, (Calgon Carbon Co., Pittsburgh, USA).

All the characteristics from the ACs produced are summed up in Table VII. As it can be seen carbons from corn stover and oat hulls (Fan et al., 2004), give the more pore volume, whereas olive seed carbons (Stavropoulos and Zabaniotou, 2005), when activated have high percentage of char yield (76\%). The higher SBET $\left(2410 \mathrm{~m}^{2} / \mathrm{g}\right)$ can be taken by pyrolyzing rice straw (Oh and Park, 2002), and activate the carbons with $\mathrm{KOH}$, but remarkable surface areas can also be taken from corn cob (Tsai et al., 2001), olive seed (Stavropoulos and Zabaniotou, 2005), and Cassava peel (Sudaryanto et al., 2006).

\section{Applications and uses of waste based active carbons}

ACs have applications in many industries as diverse as food processing, pharmaceuticals, chemical, petroleum, mining, nuclear, automobile and vacuum manufacturing, because of their adsorptive properties they have due to a high available area which is presented in their extensive internal pore struc 
Table VII. Characteristics of activated carbons from waste biomass

\begin{tabular}{|c|c|c|c|c|}
\hline Raw material & $\operatorname{SBET}\left(\mathrm{m}^{2} / \mathrm{g}\right)$ & $V_{\mathrm{o}}\left(\mathrm{cm}^{3} / \mathrm{g}\right)$ & Yield $(\%)$ & Reference \\
\hline Apricot stones & 1190 & 0.50 & 18.2 & (Savova et al., 2001) \\
\hline Cherry stones & 875 & 0.28 & 11.2 & (Savova et al., 2001) \\
\hline Grape seeds & 497 & 0.12 & 26.2 & (Savova et al., 2001) \\
\hline Nut Shells & 743 & 0.21 & 17.9 & (Savova et al., 2001) \\
\hline Pistachio-nut shells & 778 & 0.466 & - & (Lua et al., 2004) \\
\hline Macadamia nutshell & 1718 & 0.723 & - & (Ahmadroup and Do, 1997) \\
\hline- & 1169 & 0.529 & - & \\
\hline Peanut hulls & $80.8-97.1$ & $0.022-0.043$ & 30 & (Girgis et al., 2002) \\
\hline- & 253 & 0.079 & 29 & - \\
\hline- & 420 & 0.173 & 30 & - \\
\hline- & $228-268$ & $0.033-0.076$ & $27-32$ & - \\
\hline- & $240-1177$ & $0.036-0.57$ & $22-36$ & - \\
\hline Almond shells & 998 & 0.40 & 17.8 & (Savova et al., 2001) \\
\hline Almond shells & $1005.7-1217.7,1157.4-1315.4$ & & $15.84-6.34$ & (Marcilla et al., 2000) \\
\hline Oat hulls & 349 & 91.4 & - & (Fan et al., 2004) \\
\hline- & 431 & 88.4 & - & - \\
\hline- & 522 & 86.8 & - & - \\
\hline- & 625 & 84.2 & - & - \\
\hline Corn cob & $400-1410$ & $0.19-0.70$ & - & (Tsai et al., 1997) \\
\hline Corn cob & 960 & 0.486 & 28.8 & (Tsai et al., 1998) \\
\hline- & 774 & 0.349 & 30.4 & - \\
\hline- & 747 & 0.368 & 27.8 & - \\
\hline- & 682 & 0.335 & 29.2 & - \\
\hline- & 706 & 0.345 & 27.8 & - \\
\hline- & 721 & 0.342 & 28.2 & - \\
\hline Corn cob & $0.1-1.806$ & - & $12.8-31.3$ & (Tsai et al., 2001) \\
\hline- & $0.2-1.541$ & - & $17.4-33.5$ & \\
\hline Corn cob & 607 & 0.296 & 8.7 & (El-Hendawy et al., 2001) \\
\hline- & 960 & 0.629 & 18.3 & - \\
\hline- & $618-786$ & $0.321-0.430$ & $20.1-20.8$ & - \\
\hline Straw & - & - & - & (Jensen et al., 2001) \\
\hline Cotton stalk & 37.28 & - & 30.30 & (Putun et al., 2005) \\
\hline- & 3.33 & - & 29.17 & - \\
\hline- & 3.32 & - & 27.93 & - \\
\hline- & 3.14 & - & 25.56 & - \\
\hline Oak & 642 & 0.2704 & - & (Zhang et al., 2004) \\
\hline- & 644 & 0.2450 & - & - \\
\hline- & 845 & 0.3212 & - & - \\
\hline- & 985 & 0.3792 & - & - \\
\hline Corn hulls & 977 & 0.3352 & - & (Zhang et al., 2004) \\
\hline- & 902 & 0.3284 & - & - \\
\hline- & 1010 & 0.4348 & - & - \\
\hline- & 975 & 0.3792 & - & - \\
\hline Corn stover & 660 & 0.2817 & - & (Zhang et al., 2004) \\
\hline- & 432 & 0.1818 & - & - \\
\hline- & 712 & 0.2849 & - & - \\
\hline- & 616 & 0.2343 & - & - \\
\hline Corn stover & 424 & 88.7 & - & (Fan et al., 2004) \\
\hline- & 442 & 86.2 & - & - \\
\hline- & 374 & 85.0 & - & - \\
\hline- & 311 & 84.2 & - & - \\
\hline Olive-seed & 1339 & - & 76 & (Stavropoulos and Zabaniotou, 2005) \\
\hline- & 1334 & - & 72 & - \\
\hline- & 1550 & - & 65 & - \\
\hline- & 1462 & - & 59 & - \\
\hline Olive-waste cakes & $514-1271$ & $0.217-0.557$ & - & (Bacaoui et al., 2001) \\
\hline Rice-straw & 2410 & 1.4 & - & (Oh and Park, 2002) \\
\hline Rice-husk & 480 & 13.652 & - & (Yalcin and Sevinc, 2000) \\
\hline \multirow[t]{2}{*}{ Pecan shells } & 682 & - & 32 & (Ahmedna et al., 2004) \\
\hline & 724 & - & 18 & - \\
\hline Cassava peel & 1378 & 0.583 & - & (Sudaryanto et al., 2006) \\
\hline
\end{tabular}


ture. Such high porosity is a function of both the precursor as well as the scheme of activation (El-Hendawy et al., 2001).

The chemical nature of ACs significantly influences its adsorptive, electrochemical, catalytic, and other properties. Generally speaking, ACs with acidic surface chemical properties are favourable for basic gas adsorption such as ammonia while ACs with basic surface chemical properties are suitable for acidic gas adsorption such as sulphur dioxide (Yang and Lua, 2003). The uses of the AC produced by agricultural residues are summarized in Table VIII.

In gas phase adsorption

The ACs may be used as adsorbent for air pollution control, as it can effectively treat industrial gas, and indoor air environments (Tsai et al., 1998). Due to their large number of micropores and the high surface area (high adsorption capacities) they can be used as catalysts for gas purification, separation and deodorization.

Adsorption by commercial ACs offers an efficient technology for removing volatile organic compounds (VOCs) from air pollution sources, owing to their large specific surface areas, high micropore volumes and rapid adsorption capabilities (Yates et al., 2001). Furthermore, several microporous ACs from various manufacturers were selected to study the viability of using monolithic adsorption units, capable of regeneration for the purification of effluent gas streams (Yates et al., 2003).

The removal processes for $\mathrm{SO}_{x}$ and $\mathrm{NO}_{x}$ can be designed using activated carbon fiber (ACF) for the environment of busy traffic crossings, parking spaces, and large halls as well

Table VIII. Uses of activated carbons produced by waste biomass

\begin{tabular}{|c|c|c|}
\hline Raw material & Uses & Reference \\
\hline & $\begin{array}{l}\text { Treat industrial gas, indoor air } \\
\text { (air pollution control) }\end{array}$ & (Marcilla et al., 2000) \\
\hline \multirow[t]{2}{*}{ Peanut hulls, rice straw } & $\begin{array}{l}\text { Adsorption of mathylene blue } \\
\text { (liquid purification) }\end{array}$ & $\begin{array}{l}\text { (Ahmadroup and Do, 1997) and (Yalcin and } \\
\text { Sevinc, 2000) }\end{array}$ \\
\hline & Trace metals & (Ahmedna et al., 2004) \\
\hline Rice husk, orange peel & adsorption of acid dyes & $\begin{array}{l}\text { (Malik, 2003), (Chuah et al., 2005) and } \\
\text { (Ricordel et al., 2001) }\end{array}$ \\
\hline \multirow[t]{2}{*}{ Palm kernel fibre } & Removal of ions & $\begin{array}{l}\text { (Ho Y and Ofomaja, 2005) and (Kadirvelu et al., } \\
\text { (2003) }\end{array}$ \\
\hline & Removal of Arsenic & (Manju et al., 1998) \\
\hline Pitch-based carbons & Adsorption of atrazine & (Gullon and Font, 2001) and (Brown et al., 2004) \\
\hline Activated carbons membranes & Clean-up of fruits and vegetables & (Sojo et al., 1997) \\
\hline \multirow[t]{2}{*}{ Wheat straw } & Removal of nitrate and pesticides & $\begin{array}{l}\text { (Aslan and Turkman, 2005), (Kouras et al., 1995), } \\
\text { (Ayranci and Hoda, 2005) and } \\
\text { (Murayama et al., 2003) }\end{array}$ \\
\hline & $\begin{array}{l}\text { Be as support for noble } \\
\text { metals/catalysts }\end{array}$ & (Besson et al., 2005) \\
\hline Rice husks & Wastewater treatment & (Daifullah et al., 2003) \\
\hline \multirow[t]{8}{*}{ Jordanian olive stones } & Groundwater treatment & (El-Sheikh et al., 2004) \\
\hline & Purification of drinking water & (Heijman and Hopman, 1999) and (Pintar, 2003) \\
\hline & Removal of heavy metals & (Chuah et al., 2005) and (Ricordel et al., 2001) \\
\hline & Purification of effluent gas streams & (Yates et al., 2003) \\
\hline & Removal of mercury vapours & (Vitolo and Seggiani, 2002) \\
\hline & $\begin{array}{l}\text { Removal of volatile organic } \\
\text { compounds }\end{array}$ & (Yates et al., 2001) \\
\hline & Removal of $\mathrm{NO}_{\mathrm{x}}$ and $\mathrm{SO}_{\mathrm{x}}$ & (Mochida et al., 2000) \\
\hline & $\begin{array}{l}\text { Removal of phenols and phenolic } \\
\text { compounds }\end{array}$ & (Dabrowski et al., 2005) and (Dursun et al., 2005) \\
\hline
\end{tabular}


as for exhaust gases such as the flue gas from a power plant, catalyst regeneration for fluidized catalytic cracking (FCC) process, and ventilated gas from motorway tunnels (Mochida et al., 2000). Activated carbon are also used for removing mercury vapours from a gas mixture containing $\mathrm{H}_{2} \mathrm{~S}, \mathrm{O}_{2}$ and moisture that is representative of the exhaust gas emissions of the geothermal power plants (Vitolo and Seggiani, 2002).

\section{In liquid phase adsorption}

Liquid phase adsorption applies to many purification processes. The most relevant is the wastewater treatment e.g. by rice husk carbons (Daifullah et al., 2003), the drinking water (Heijman and Hopman, 1999), the industrial effluents purification (Pintar, 2003), and ground water treatment e.g. Jordanian olive stones (El-Sheikh et al., 2004).

Adsorption of methylene blue has been one of the most important means of assessing removal capacity from the aqueous phase. Phosphoric acid-ACs are the best in the uptake of methylene blue from aqueous solution (200-400 $\mathrm{mg} / \mathrm{g}$ ) (Girgis et al., 2002). Porous carbons with high surface area and adsorption capacities for methylene blue and iodine could be obtained from a rice straw precursor ( $\mathrm{Oh}$ and Park, 2002), particularly by the two-stage method, in which the raw rice straw is carbonized at the first stage and activated with $\mathrm{KOH}$ at the subsequent stage. From the one-stage method the porous ACs of only moderate performance could be obtained, because the ash-formation makes it difficult to increase the optimum temperature at which micropores can be created.

ACs are used for the removal of phenols, phenolic compounds (Dabrowski et al., 2005) and (Dursun et al., 2005), heavy metals and dyes (Chuah et al., 2005) and (Ricordel et al., 2001), metal ions (Ho Y and Ofomaja, 2005) and (Kadirvelu et al., 2003) and mercury (II) from aqueous solutions. Phenolic derivatives belong to a group of common environmental contaminants. The presence of these compounds even in low concentrations can be an obstacle to the use and/or reuse of water. Phenols cause unpleasant taste and odour of drinking water and can exert negative effects on different biological processes. Phenolic derivatives are widely used as intermediates in the synthesis of plastics, colours, pesticides, insecticides, etc. Degradation of these substances means the appearance of phenol and its derivatives in the environment (Dabrowski et al., 2005). They can also adsorb arsenic (As) (Manju et al., 1998) and trace metals (Ahmedna et al., 2004) from drinking water, or be used as support for noble metals or as catalysts per se in liquid phase reactions (Besson et al., 2005).

Adsorption of acid dyes from aqueous solution, like acid violet 17 from waste waters, by orange peel carbons, or acid yellow 36 by rice husk carbons (Malik, 2003), is one of the most efficient methods. Carbons with low dye uptake (30$100 \mathrm{mg} / \mathrm{g}$ ) are those chemically activated with $\mathrm{ZnCl}_{2}, \mathrm{KOH}$, steam pyrolyzed or chars (Girgis et al., 2002).

\section{Active carbon for organics-pesticides}

ACs are very efficient in the adsorption of nitrate and pesticides from surface waters (Aslan and Turkman, 2005), (Kouras et al., 1995), (Ayranci and Hoda, 2005) and (Murayama et al., 2003). Pitch-based AC fibres are more effective in the atrazine removal dynamic tests than granular activated carbon if they are highly activated. The rapid adsorption kinetics of the atrazine with the highly activated ACF seems to be the main reason for its having a better performance than granular AC (GAC). This means that a fibertype structure with micropores directly accessible from the surface is not enough reason to justify the good efficiency of ACF (Gullon and Font, 2001). Another carbon based material, Nyex 100 (Brown et al., 2004), was also used for the removal of atrazine to low levels, below $1 \mu \mathrm{g}^{-1}$.

The feasibility of using AC membranes as the solid phase for an on-line single step extraction-cleanup of fruits and vegetables for multi residue screening was studied in (Sojo et al., 1997). The type of carbon present in these membranes (an acid-washed coconut charcoal) seems to be able to discriminate between compounds containing benzene rings with small substituents from those with bulky substituents. The origin of this selectivity may be due to the presence of active sites on the carbon surface. It is speculated that these sites are electron deficient sites, which could be deactivated by exposure to reducing agents, such as ascorbic acid. This is a property that could be exploited in the cleanup of samples for the isolation of compounds such as polyaromatic hydrocarbons (PAHs) and polychlorinated biphenyls (PCBs) from complex matrices such as soils and sediments.

\section{Comparisons of active carbons}

Commercial carbons can be used satisfactorily, as post treatment in order to adsorb colour, nitrate and dissolved organic carbon from drinking water, effluent water (Aslan and 
Table IX. Uses of commercial activated carbons

\begin{tabular}{lll}
\hline PAC/Chemviron & Dodine (surface waters) & (Kouras et al., 1995) \\
\hline ACF/Spectra corp & Atrazine (kinds of pesticides for water waste treatment) & (Ayranci and Hoda, 2005) \\
Nyex 100 & Atrazine (aqueous solutions) & (Brown et al., 2004) \\
ACF/KF-175, TOYOBO & Organic chlorine pesticides (water samples) & (Murayama et al., 2003)
\end{tabular}

Turkman, 2005). Organic pollutants, like different kind of pesticides, are also being removed by either powdered or granular or fiber ACs. Kouras et al., 1995, showed that powdered active carbon produced by Chemviron was very effective in cleaning surface waters by the adsorption of dodine. The result was even better when using coagulants (polyelectrolyte, $\mathrm{Al}, \mathrm{Fe}$ ). The highest removal observed when mixing $50 \mathrm{mg} / \mathrm{l}$ PAC with ferric chloride (>98.2\%). Ayranci et al., 2005, supported that ACF, and especially pitch-based, was more effective in the removal of atrazine than granular AC. In their tests for waste-water purification it turned up that ACF (from Spectra corp.) had very high specific surface area, adsorption capacity and mechanical strength. A new collection method of organic chlorine pesticides in water samples (rainwater, river water, seawater) using an ACF filter (KF-175, TOYOBO) was proposed in the study of Murayama et al., 2003, to be effective and economical compared to those by the conventional method. Finally, Brown et al., 2004, used a novel carbon-based adsorbent material (Nyex 100) for the removal of atrazine to low levels, below $1 \mu \mathrm{g}^{-1}$, from aqueous solutions, which regenerated electrochemically, and has the ability to reach three times greater adsorptive capacities than originally achieved. This material does not have internal surface and porous, and it has low cost. Table IX summarizes the uses of commercial active carbons.

\section{Conclusion}

\section{Concerning type of waste biomass}

Activated carbons from almond shell, nut shell, apricot and cherry stones, have low ash content in contrast with the carbon from grape seeds which has relatively high ash content. All samples have low sulphur content. The following order of suitability of raw materials for activated carbon production was established: hazelnut shell $>$ apricot stone $>$ almond shell. The higher yields of activated carbons with high $\mathrm{S}_{\mathrm{BET}}$ obtained from olive wastes, birch and bagasse, make these raw materials suitable for preparation of activated carbon while samples from straw and miscanthus seem more suitable for conversion into liquid and gaseous products.

\section{Concerning process parameters}

Both the hydrogen and oxygen contents of char and hence $\mathrm{H} / \mathrm{C}$ ratio decreases as the temperature is increased indicating an increase in the aromaticity and carbonaceous nature of char. SBET and the total pore volume increase with pyrolysis temperature, and reach a maximum at about $500{ }^{\circ} \mathrm{C}$; thereafter, the trend is a decrease with pyrolysis temperature. The rate of declination is not as fast as that of increase. However, increase in temperature from 500 to $800{ }^{\circ} \mathrm{C}$ may induce shrinkage in the carbon structure, resulting in a reduction in the surface area and the pore volume.

Moreover, it seems that the soaking time in the chemical activation plays a less important role in the production of activated carbon. It is seen that, by increasing soaking time, the surface area and the pore volume were increased as a result of the development of porosity. However, the values thereafter are observed to decrease gradually at longer soaking time, which is possibly attributed to the gasification of the few well developed micropore wall. $\mathrm{S}_{\mathrm{BET}}$ increase with an increase of the burn-off, which proved to be the most significant factor, regardless of the activation temperature.

\section{Concerning type of activation}

The experimental results of Macadamia nutshells show that surface area and micropore volume of the samples produced by chemical activation with $\mathrm{ZnCl}_{2}$ are much higher than those with $\mathrm{KOH}$. High-quality of carbon can easily be produced from peanut hulls through chemical activation with $\mathrm{H}_{3} \mathrm{PO}_{4}$ at $500{ }^{\circ} \mathrm{C}$. 


\section{Concerning uses of active carbons}

Activated carbons prepared with the pistachio-nut shells can be used for both gas and liquid adsorption applications, depending on the activation conditions. Peanut husks carbon is an effective adsorbent for the removal of $\mathrm{Pb}^{2+}, \mathrm{Cd}^{2+}, \mathrm{Zn}^{2+}$ and $\mathrm{Ni}^{2+}$ from aqueous solutions. It would be useful for the economic treatment of wastewater containing these heavy metals, as the adsorbent has a much superior capacity to the commercial activated carbon.

Copper-impregnated coconut husk carbon can be used as an adsorbent for the effective removal of As(III) from aqueous solutions. The carbonized product from beet pulp is an efficient adsorbent for the removal of phenol from aqueous solution.

Three grades of carbons were obtained from corn cobs: (a) Those obtained by carbonization yields a poorly developed wide-pored carbon with capacity for iodine and $\mathrm{Pb}^{2+}$ ions; (b) steam-activated carbons (in one or two step schemes) develop porosity with temperature, and are essentially microporous. These exhibit good adsorbing affinity from solution (iodine, phenol, and methylene blue) that depends on their porosity characteristics; (c) chemical activation by $\mathrm{H}_{3} \mathrm{PO}_{4}$ at $500{ }^{\circ} \mathrm{C}$ proved very effective in producing high quality activated carbon with well-developed porosity and high adsorption capacity for both organic and inorganic substrates.

Almond shell-based carbon with steam-activated pecan shell- removed nearly $100 \%$ of lead ion, $90-95 \%$ of copper ion and $80-90 \%$ of zinc ion. Acid activation resulted in higher yield, lower surface area, higher percentage of micropore compared to steam activation. Percent yield is a factor used in cost estimation and commercial potential of activated carbons.

\section{References}

Ahmadroup A and Do DD (1997), The preparation of activated carbon from Macadamia nutshell by chemical activation, Carbon, 35: 1723-1732.

Ahmedna M, Marshall WE, Husseiny AA, Rao RM and Goktepe I (2004), The use of nutshell carbons in drink- ing water filters for removal of trace metals, Water Res, 38: 1062-1068.

Ahmedna M, Marshall WE and Rao RM (2001), Production of granular activated carbons from select agricultural by-products and evaluation of their physical, chemical and adsorption properties, Bioresource Technol, 71: 113-123.

Aslan S and Turkman A (2005), Combined biological removal of nitrate and pesticides using wheat straw as substrates, Process biochem, 40: 935-943.

Aygun A, Yenisoy-Karakas S and Duman I (2003), Production of granular activated carbon from fruit stones and nutshells and evaluation of their physical, chemical and adsorption properties, Micropor Mesopor Mater, 66: 189-195.

Ayranci E and Hoda N (2005). Adsorption kinetics and isotherms of pesticides onto activated carbon-cloth, Chemosphere, 60: 1600-1607.

Bacaoui A, Yaacoubi A, Dahbi A, Bennouna C, Phan Tan Luu R and Maldonado-Hodar FJ (2001), Optimization of conditions for the preparations of activated carbons from olive-waste cakes, Carbon, 39: 425-432.

Besson M, Gallezot P, Perrard A and Pinel C (2005), Active carbons as catalysts for liquid phase reactions, Catal Today, 102-103: 160-165.

Brown N W, Roberts EPL, Chasiotis A., Cherdron T and Sanghrajka N (2004), Atrazine removal using adsorption and electrochemical regeneration, Water Res, 38: 3067-3074.

Cetin E, Moghtaderi B, Gupta R and Wall TF (2004), Influence of pyrolysis conditions on the structure and gasification reactivity of biomass chars, Fuel, 83: 2139-2150.

Chuah TG., Jumasiah A, Azni I., Katayon S and Thomas SY (2005), Rice husk as a potentially low-cost biosorbent for heavy met al and dye removal: an overview, Desalination, 175: 305-316. 
Dabrowski A, Podkoscielny P, Hubicki Z and Barczak M (2005), Adsorption of phenolic compounds by activated carbon-a critical review, Chemosphere, 58: 10491070.

Daifullah AAM, Girgis BS and Gad HMH (2003), Utilization of agro-residues (rice husk) in small waste water treatment plans, Mater Lett, 57: 1723-1731.

Dursun G, Cicek H and Dursun AY (2005), Adsorption of phenol from aqueous solution by using carbonised beet pulp, J Hazard Mater, 125: 175-182.

El-Hendawy ANA, Samra SE and Girgis BS (2001), Adsorption characteristics of activated carbons obtained from corncobs, Colloid Surface A: Physicochem Eng Aspects, 180: 209-221.

El-Sheikh AH, Newmana AP, Al-Daffaee HK., Phull S and Cresswell N (2004), Characterization of activated carbon prepared from a single cultivar of Jordanian Olive stones by chemical and physicochemical techniques, $J$ Anal Appl Pyrol, 71: 151-164.

Fan M, Marshall W, Daugaard D. and Brown RC (2004), Steam activation of chars produced from oat hulls and corn stover, Bioresource Technol, 93: 103-107.

Girgis BS, Yunis SS and Soliman AM (2002), Characteristics of activated carbon from peanut hulls in relation to conditions of preparation, Mater Lett, 57: 164-172.

Gullon MI and Font R (2001), Dynamic pesticide removal with activated carbon fibers, Water Res, 35: 516-520.

Haykiri-Acma H, Yaman S and Kucukbayrak S (2006), Gasification of biomass chars in steam-nitrogen mixture. Energy Conversion Management, 47 (7-8): 10041013.

Heijman SGJ and Hopman R (1999), Activated carbon filtration in drinking water production: model prediction and new concepts, Colloid Surface A: Physicochem Eng Aspects, 151: 303-310.
Ho YS and Ofomaja AE (2005). Kinetics and thermodynamics of lead ion sorption on palm kernel fibre from aqueous solution Process, Biochemistry, 40: 3455-3461.

Jensen PA, Sander B and Dam-Johansen K (2001), Pretreatment of straw for power production by pyrolysis and char wash, Biomass Bioenergy, 20: 431-446.

Kadirvelu K, Kavipriya M, Karthika C, Radhika M, Vennilamani N and Pattabhi S (2003), Utilization of various agricultural wastes for activated carbon preparation and application for the removal of dyes and metal ions from aqueous solutions, Bioresource Technol, 87: 129-132.

Kouras A, Zouboulis A, Samara C and Kouimtzis T (1995), Removal of pesticides from surface waters by combined physicochemical process. Part I: dodine, Chemosphere, 30: 2307-2315.

Lanzetta M. and Di Blasi C (1998), Pyrolysis kinetics of wheat and corn straw, J Anal Appl Pyrol, 44: 181-192.

Lua AC, Yang T and Guo J (2004), Effects of pyrolysis conditions on the properties of activated carbons prepared from pistachio-nut shells, J Anal Appl Pyrol, 72: 279287.

Mahanim SMA, Wan Asma I, Rafdah J, Puad E and Shaharuddin H. (2011), Production of activated carbon from industrial bamboo wastes. Journal of Tropical Forest Science, 23(4): 417-424.

Malik PK (2003), Use of activated carbons prepared from sawdust and rice-husk for adsorption of acid dyes: a case study of Acid Yellow 36, Dyes Pigments, 56: 239249.

Manju GN, Raji C and Anirudhan TS (1998), Evaluation of coconut husk carbon for the removal of arsenic from water, Water Res, 32: 3062-3070.

Marcilla A, Garcia-Garcia S, Asensio M and Conesa JA (2000), Influence of thermal treatment regime on the density and reactivity of activated carbons from almond shells, Carbon, 38: 429-440. 
Minkova V, Marinov SP, Zanzi R, Bjornbom E, Budinova T and Stefanova M (2000), Thermochemical treatment of biomass in a flow of steam or in a mixture of steam and carbon dioxide, Fuel Process Technol, 62: 45-52.

Minkova V, Razvigorova M, Bjornbom E, Zanzi R, Budinova T and Petrov N (2001), Effect of water vapour and biomass nature on the yield and quality of the pyrolysis products from biomass, Fuel Proc Technol, 70: 53-61.

Mochida I, Koraia Y, Shirahama M, Kawano S, Hada T and Seo Y (2000), Removal of SO and NO over activated carbon fibers, Carbon, 38: 227-239.

Murayama H, Moriyama N, Mitobe H, Mukai H. and Takase Y. (2003) Evaluation of activated carbon fiber filter for sampling of organochlorine pesticides in environmental water samples, Chemosphere, 52: 825-833.

Namasivayam C and Kadirvelu K (1999), Uptake of mercury (II) from wastewater by activated carbon from an unwanted agricultural solid by-product: coirpith, Carbon, 37: 79-84.

Oh GH and Park CR (2001), Preparation and characteristics of rice-sraw-based porous carbons with high adsorption capacity, Fuel, 81: 327-336.

Pintar A. (2003), Catalytic processes for the purification of drinking water and industrial effluents, Catal Today, 77: 451-465.

Predel M. and Kaminsky W (1998), Pyrolysis of rape-seed in a fluidized-bed reactor, Bioresource Technol, 66: 113117.

Putun AE, Ozbay N, Onal EP and Putun E (2005), Fixed-bed pyrolysis of cotton stalk for liquid and solid products, Fuel Process Technol, 86: 1207-1219.

Ricordel S, Taha S, Cisse I. and Dorange G (2001), Heavy metals removal by adsorption onto peanut husks carbon: characterization, kinetic study and modelling, Sep Purif Technol, 24: 389-401.
Savova D, Apak E, Ekinci E, Yardim F, Petrova N and Budinova T (2001), Biomass conversion to carbon adsorbents and gas, Biomass Bioenergy, 21: 133-142.

Sivaraj R, Namasivayam C and Kadirvelu K (2001), Orange peel as an adsorbent in the removal of Acid violet 17 (acid dye) from aqueous solutions, Waste Manage, 21: 105-110.

Skoulou V and Zabaniotou A (2007), Investigation of agricultural and animal wastes in Greece and their allocation to potential application for energy production, Renew Sustain Energy Rev, 11 (8): 1698-1719.

Sojo LE, Brocke A, Fillion J and Price SM (1997), Application of activated carbon membranes for on-line cleanup of vegetable and fruit extracts in the determination of pesticide multiresidues by gas chromatography with mass selective detection, $J$ Chromatogr $A, \mathbf{7 8}$ : 141-154.

Stavropoulos GG. and Zabaniotou AA (2005), Production and characterization of activated carbons from oliveseed waste residue, Micropor Mesopor Mater, 82: 7985.

Sudaryanto Y, Hartono SB, Irawaty W, Hindarso H and Ismadji S (2006), High surface area activated carbon prepared from cassava peel by chemical activation, Bioresource Technol, 97: 734-739.

Tsai WT, Chang CY and Lee SL (1998), A low cost adsorbent from agricultural waste corn cob by zinc chloride activation, Bioresource Technol, 64: 211-217.

Tsai WT, Chang CY. and Lee SL. (1997) Preparation and characterization of activated carbons from corn cob, Carbon, 35: 1198-1200.

Tsai WT, Chang CY, Wang SY, Chang CF, Chien SF and Sun HF. (2001), Cleaner production of carbon adsorbents by utilizing agricultural waste corn cob, Resour Conserv Recy, 32: 43-53.

Vitolo S and Seggiani M (2002), Mercury removal from geothermal exhaust gas by sulfur-impregnated and virgin activated carbons, Geothermics, 31: 431-442. 
Yalcin N and Sevinc V (2000), Studies of the surface area and porosity of activated carbons prepared from rice husks, Carbon, 38: 1943-1945.

Yang T and Lua AC (2003), Characteristics of activated carbons prepared from pistachio-nut shells by physical activation, J Colloid Interf Sci, 267: 408-417.

Yates M, Blanco J, Avila P. and Martin MP. (2000), Honeycomb monoliths of activated carbons for effluent gas purification, Micropor Mesopor Mater, 37: 201-208.
Yates M, Blanco J, Martin-Luengo MA and Martin MP (2003), Vapour adsorption capacity of controlled porosity honeycomb monoliths, Micropor Mesopor Mater, 65: 219-231.

Zhang T, Walawender WP, Fan LT, Fan M, Daugaard D and Brown RC (2004), Preparation of activated carbon from forest and agricultural residues through $\mathrm{CO}_{2}$ activation, Chem Eng J, 105: 53-59

Received: 16 November 2011; Revised: 12 December 2011; Accepted: 15 January 2012 . 